Viso - Cadernos de estética aplicada Revista eletrônica de estética

ISSN 1981-4062

$N^{\circ} 22$, jan-jun/2018

http://www.revistaviso.com.br/
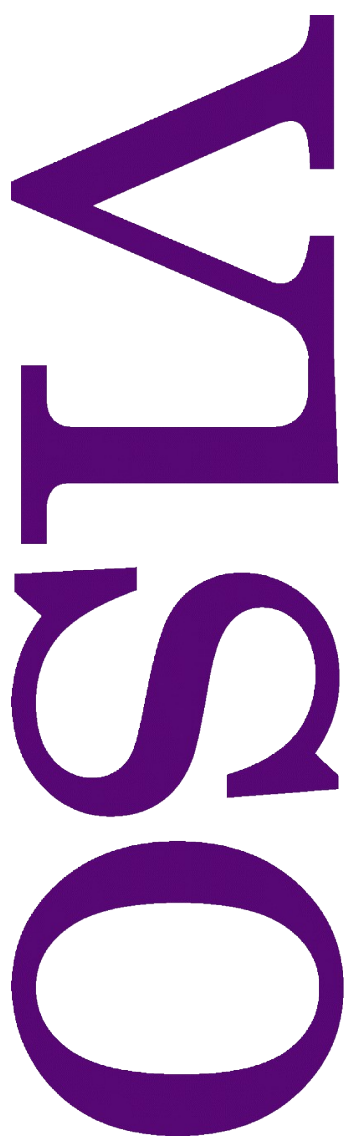

\title{
A tensão entre imagem e linguagem em Descrição de imagem, de Heiner Müller e L'image, de Samuel Beckett Danilo Riva de Moraes
}




\section{RESUMO}

A tensão entre imagem e linguagem em Descrição de imagem, de Heiner Müller e L'image, de Samuel Beckett

Por meio de análise das obras Descrição de imagem, de Heiner Müller e "L'image" [A imagem], de Samuel Beckett, o presente artigo analisa a complexa relação entre imagem e linguagem, buscando compreender possíveis imbricamentos dessas duas instâncias nas referidas obras. Não parece mais viável - ou até mesmo possível - pensar a literatura e as artes visuais como domínios absolutamente distintos, com limites claramente estabelecidos. Os textos de Müller e de Beckett justamente propõe novos modos de compreensão das instâncias do visível e do invisível, do sonoro e do silêncio, do quadro e a da escrita, enfim, da imagem e da linguagem.

Palavras-chave: imagem - linguagem - Heiner Müller - Samuel Beckett

\section{ABSTRACT}

The Tension between Heiner Müller's Description of a Picture and Samuel Beckett's The Image

Through the analysis of the works "Description of a Picture", by Heiner Müller and "The Image", by Samuel Beckett, this essay analyzes the complex relation between image and language in an attempt to understand the possible relation between the subjects in these works. No longer seems feasible - or even possible - to think the literature and the visual arts as absolutely distinct areas, with clearly defined limits. The Müller and Beckett texts rightly proposes new ways of understanding the instances of visible and invisible, sound and silence, the frame and the writing, finally, image and language.

Keywords: image - language - Heiner Müller - Samuel Beckett 
RIVA, D. "A tensão entre imagem e linguagem em Descrição de imagem, de Heiner Müller e L'image, de Samuel Beckett". In: Viso: Cadernos de estética aplicada, v. XII, n. 22 (jan-jun/2018), pp. 36-56.

DOI: $10.22409 / 1981-4062 / v 22 i / 238$

Aprovado: 16.03.2018. Publicado: 30.06.2018.

(C) 2018 Danilo Riva de Moraes. Esse documento é distribuído nos termos da licença Creative Commons Atribuição-NãoComercial 4.0 Internacional (CC-BY-NC), que permite, exceto para fins comerciais, copiar e redistribuir o material em qualquer formato ou meio, bem como remixá-lo, transformá-lo ou criar a partir dele, desde que seja dado o devido crédito e indicada a licença sob a qual ele foi originalmente publicado.

Licença: http://creativecommons.org/licenses/by-nc/4.0/deed.pt_BR

Accepted: 16.03.2018. Published: 30.06.2018.

(C) 2018 Danilo Riva de Moraes. This document is distributed under the terms of a Creative Commons Attribution-NonCommercial 4.0 International license (CC-BY-NC) which allows, except for commercial purposes, to copy and redistribute the material in any medium or format and to remix, transform, and build upon the material, provided the original work is properly cited and states its license.

License: http://creativecommons.org/licenses/by-nc/4.0/ 


\section{Introdução}

As relações entre imagem e linguagem vêm sendo abordadas, historicamente, por diversos estudiosos, seja o caso de Lessing, por exemplo, em seu Laocoonte, ou sobre as fronteiras da pintura e da poesia (1766), onde estas instâncias são compreendidas como absolutamente distintas; seja em A obra-prima ignorada (1831), de Honoré de Balzac, onde o autor cria, na escrita, um quadro, uma imagem, que só existe na e pela linguagem.

Para pensar este imbricamento entre imagem e linguagem, o presente trabalho tomou como ponto de partida as obras Descrição de imagem (1984), de Heiner Müller, e L'image (1959), de Samuel Beckett, por compreender que essas duas instâncias são, de alguma forma, tematizadas nesses dois textos e serão aqui problematizadas.

O trabalho é constituído de três partes, cada qual abordando a relação entre imagem e linguagem por uma perspectiva distinta. A primeira parte se dedica à escrita, pensando nos recursos utilizados pelos dois autores, como a eliminação de sinais de pontuação no texto beckettiano, por exemplo, e o recurso da intertextualidade no texto de Heiner Müller, em uma tentativa de fazer imagens pela linguagem.

A segunda parte diz respeito à recepção, refletindo sobre como as escritas peculiares de Beckett e Müller, nessas duas obras, implicam uma nova recepção, o receptor se torna um coprodutor, como afirma Hans-Thies Lehmann, ou seja, ele participa, de algum modo, da construção daquilo que lê e daquilo que ouve.

Por fim, a última parte se detém na questão da imagem, tomando como base três aspectos que viabilizam a realização da análise pretendida: o primeiro aspecto é a voz narrativa, presente nas duas obras e que é a responsável por realizar a descrição das imagens; o segundo aspecto aponta para o problema do visível e do invisível, pensando também como há uma dimensão temporal implicada na construção desse visível; e, por último, o terceiro aspecto aborda a cisão do sujeito que vê e é visto, pensando no desdobramento daquele que vê naquilo que é visto.

\section{Linguagem: A transposição do visual para a escrita}

\subsection{L'image}

L'image, de Samuel Beckett, foi publicado, inicialmente, em 1959, como um texto independente. Em 1961, porém, ele foi publicado como parte integrante do romance Comment c'est, escrito originalmente em francês, mas traduzido pelo próprio Beckett para o inglês e publicado em 1964 com o título How it is. 
Um dos aspectos que, logo de início, chamam a atenção do leitor é o fato de o texto ser escrito integralmente sem fazer a utilização de nenhum sinal de pontuação, com exceção de um único ponto final, que marca, justamente, o momento em que o texto se encerra, quando a imagem está feita.

É possível notar, porém, que ainda que o autor não insira graficamente o ponto final em outros trechos do texto, há dois momentos em que aparece a palavra "point" [ponto] parecendo exercer a mesma função do sinal gráfico correspondente ao ponto final. Claro, esta é apenas uma hipótese de leitura e, a fim de tentar compreendê-la melhor, se faz necessário um retorno ao texto de Beckett, para o primeiro momento em que a palavra aparece:

[...] a julgar pelas flores que se espalham a erva esmeralda nós estamos no mês de abril ou de maio eu ignoro e com que alegria de onde eu tiro essas histórias de flores e de estações eu as tenho e ponto é tudo a julgar por certos acessórios cuja barreira branca e uma tribuna de um vermelho requintado nós estamos em um campo de corrida [...]. ${ }^{1}$

Ao mesmo tempo em que a voz cria histórias - este é um outro aspecto a ser ressaltado no texto, pois sabe-se que há uma voz, mas não se sabe, exatamente, de onde essa voz fala -, ela ignora de onde saem tais histórias. No trecho citado anteriormente, a palavra "ponto" parece interromper momentaneamente o fluxo de criação de histórias - ou, talvez possa ser dito também, criação de imagens. A expressão "é tudo" parece reforçar essa hipótese da interrupção, pois aponta para o fato de que não é preciso saber de onde são tiradas essas histórias, tê-las é o bastante para continuar a história, tanto que após o "ponto é tudo" a voz retoma a criação da imagem que estava sendo construída antes da interrupção da palavra "ponto".

No segundo momento em que a palavra "ponto" aparece, exercendo a mesma função que no caso citado acima, ela é acompanhada, novamente, da expressão "é tudo":

[...] pouco a pouco manchas cinzas e brancas aos quais eu não tardo a dar o nome de carneiro no meio de suas mães eu ignoro de onde eu tiro as histórias de animais eu as tenho ponto é tudo em um bom dia eu sei nomear quatro ou cinco cães de raças totalmente diferentes $[\ldots]^{2}$

Ainda para pensar sobre a questão da ausência de sinal de pontuação em L'image, parece interessante recorrer à reflexão feita por Adorno em seu texto "Sinais de pontuação", um dos ensaios que compõem a obra Notas de literatura I:

Todos [os sinais de pontuação] são sinais de trânsito; afinal, estes o tomaram como modelo. Pontos de exclamação correspondem ao vermelho; dois pontos, verde; e os travessões ordenam stop. Mas foi um erro da Escola de George ${ }^{3}$ confundi-los, por causa disso, com sinais de comunicação. ${ }^{4}$

Levando em conta esta passagem da obra de Adorno, é possível pensar nos sinais de pontuação como sendo os elementos responsáveis por indicar como se deve transitar 
pelo texto. Nesse sentido, é possível pensar no texto beckettiano como uma obra aberta, na medida em que possibilita que o leitor trafegue livremente por ela, fazendo com que o mesmo texto possa ser lido de maneiras distintas criando variações dependendo do local em que o receptor "insere" a pontuação no momento da leitura.

Mais adiante, no mesmo ensaio, Adorno afirma que os sinais de pontuação

são sobretudo sinais de elocução. Em vez de zelosamente servirem ao trânsito entre a linguagem e o leitor, funcionam como hieróglifos no tráfego que acontece no interior da linguagem, em suas próprias vias. É supérfluo, por isso, omiti-los como supérfluos: assim eles apenas se escondem. ${ }^{5}$

Seguindo a reflexão feita por Adorno e retomando o texto de Beckett, pode-se dizer que em L'image é posto o problema sobre como dizer o texto e também sobre como ler o texto, afinal, os sinais de pontuação são, também, indicações visuais. A imagem se constitui na linguagem, porém dentro de um movimento de aparecimento e desaparecimento - essa questão também será trabalhada mais detidamente na terceira parte do trabalho -, o que por si só já representa um problema significativo na tentativa de criar uma imagem na escrita. $O$ fato de não haver sinais de pontuação no decorrer do texto acaba sendo mais um elemento a ser levado em conta para se pensar o problema da voz narrativa, que é também o de como dizer a imagem, ou de como fazer a imagem.

Tendo ainda como foco a escrita em L'image, um outro ponto que pode ser levado em consideração é o fato de que só há uma única letra maiúscula no texto todo, uma letra "L" na frase em que a narrativa se inicia: "La langue se charge de boue". ${ }^{6}$ O próprio título do livro é escrito com a inicial minúscula. Considerando então que só há uma letra maiúscula, no início do texto, e somente um ponto final, marcando o encerramento da escrita, pode-se pensar que L'image se constitui de uma única e longa frase. Ao se deparar com a obra de Beckett, portanto, o leitor se depara com um bloco textual que é, na realidade, uma única frase que ocupa dez páginas de um livro. Sendo assim, pode-se dizer que o texto apresenta ao leitor alguns desafios - ou até mesmo dificuldades - para a realização de sua leitura, mas essa questão sobre a recepção será abordada mais adiante.

\section{2. "Descrição de Imagem"}

O outro texto tomado como objeto de estudo do presente trabalho é Descrição de imagem [Bildbeschreibung], do dramaturgo alemão Heiner Müller. A peça foi escrita em 1984 a partir de um desenho feito por uma estudante de cenografia em Sófia, na Bulgária. Em sua autobiografia, intitulada Guerra sem batalha: uma vida entre duas ditaduras, Müller escreve brevemente sobre o processo de criação do texto: 
O motivo foi um desenho, ligeiramente colorido, de uma estudante de cenografia de Sófia. Ela tinha desenhado um sonho. Ela não tinha lido Freud, era espontâneo, sem qualquer inibição diante dos símbolos. Comecei descrevendo o desenho. [...] Descrever um quadro significa também cobri-lo com escrita. A descrição traduz o quadro para um outro meio. [...] A estrutura do texto é que um quadro questiona o outro. Uma camada apaga sempre a presente e a ótica muda. ${ }^{7}$

A obra de Müller se constitui, nesse caso, em um movimento de tradução de um meio para outro, do meio das artes visuais para o meio literário e, ao descrever aquela imagem do desenho, que estava em sua memória, inevitavelmente, o dramaturgo cria novas imagens, sempre dentro de um processo, segundo o próprio Müller, de apagamento de uma camada pela sobreposição de outra.

Em um artigo nomeado "Espaços livres para a fantasia: Descrição de imagem, de Heiner Müller", o professor e pesquisador Luciano Gatti escreve que essa "transposição do médium visual para a escrita resulta num gênero singular: uma frase única, com redução extrema das convenções teatrais, e ainda assim um texto concebido para o teatro". ${ }^{8}$ É possível pensar, aqui, em uma primeira relação entre Descrição de imagem e L'image, pois ambos rompem com convenções em suas escritas, seja pela presença de um único ponto final no texto de Beckett, seja pelo fato de ambos serem escritos em uma frase única, ou ainda, como afirma Gatti, pela "redução extrema das convenções teatrais", característica do texto de Müller, mas que também está presente em diversos textos teatrais de Samuel Beckett. Cabe aqui uma ressalva no que diz respeito ao fato de os dois textos serem escritos em uma única frase: no caso de L'image, essa questão parece mais evidente, como dito anteriormente, pela presença da letra maiúscula no início do texto e o uso do ponto final somente no término da escrita. No caso de Descrição de imagem, essa afirmação pode ser questionada, talvez, pelo fato de o autor fazer uso de sinais de pontuação. Ainda que haja, como em Beckett, só uma letra maiúscula e somente um ponto final, Heiner Müller faz uso de sinais como, por exemplo, a vírgula e os dois pontos, o que a abre a possibilidade de se pensar no texto como sendo constituído de várias frases, ou ainda, uma frase maior que se subdivide em diversas frases menores.

Uma outra característica presente não só em Descrição de imagem, mas em toda - ou quase toda - a dramaturgia mülleriana é a intertextualidade. Há, nas obras deste dramaturgo, sempre uma polifonia de vozes advindas de autores, épocas e textos distintos. A este respeito, em seu livro O teatro de Heiner Müller, Ruth Röhl escreve que essa relação de intertextualidade

se faz portanto como numa via de mão dupla, na medida em que, participando na história da recepção de literatura, o texto convive também com a posteridade. [...] Excluindo o período da dramaturgia burguesa, cujo conceito de originalidade associa ao de propriedade, ele [Heiner Müller] caracteriza o texto dramático como um produto tardio, fruto de uma crise (RÖHL, 1997, p.27). ${ }^{9}$ 
Analisar as referências possíveis às outras obras citadas em Descrição de imagem certamente exige um trabalho de maior fôlego, dedicado unicamente a essa questão. 0 que realmente diz respeito ao presente trabalho, no que toca à intertextualidade, é o fato de que, ao recorrer a outras obras, Müller insere na descrição da imagem original, o desenho da estudante búlgara, outras imagens, o que faz com que sua obra ganhe 0 aspecto de um palimpsesto ${ }^{10}$, como afirma o encenador francês Jean Jourdheuil em artigo publicado na Europa Revue, no ano de 2006.

Seguindo a tradução feita por Jourdheuil para a nota escrita por Müller ao final do texto, nota-se que o próprio dramaturgo utiliza a ideia de palimpsesto para falar de sua obra: "Descrição de imagem pode ser considerada como um palimpsesto [Übermalung] de imagens e de referências provenientes de Alceste, da peça Nô Kumasaka, do Canto XI da Odisseia, de Os pássaros de Hitchcock e de A tempestade, de Shakespeare". ${ }^{11}$

Há uma tradução para a língua portuguesa, publicada em 1993, que traduz a palavra Übermalung por retoque. No caso da língua inglesa, Übermalung pode ser traduzida por overpainting que, numa tradução literal para o português, seria algo como "sobrepintura". Por esse motivo, parece mais adequada a tradução que Jean Jourdheuil faz para o francês, utilizando a palavra palimpseste para traduzir Übermalung. A ideia de palimpsesto é bastante pertinente quando se pensa que todas essas referências às quais Müller se dirige criam novas camadas textuais sobre a descrição realizada pelo autor, formando o que Jourdheuil nomeia de "rede complexa de relações literárias". ${ }^{12} \mathrm{O}$ encenador francês faz ainda uma observação sobre os palimpsestos, apontando para o fato de que estes, na maioria dos casos, não são realizados a partir de obras desconhecidas, mas de obras célebres. Como exemplo disso, Jourdheuil recorre a uma tela de Bacon ${ }^{13}$, "que é um palimpsesto do retrato de um papa feito por Velázquez, ou As meninas, de Picasso, que são um palimpsesto da tela homônima do mesmo Velázquez". ${ }^{14} \mathrm{O}$ próprio Canto XI da Odisseia, uma das referências de Müller, também foi, segundo Jourdheuil, "objeto de palimpsesto, o primeiro dos Cantos de Ezra Pound, e é ainda Ezra Pound que o conduz [Heiner Müller] a se interessar pelo Nô Kumasaka”. ${ }^{15}$

Em sua tese de doutorado, intitulada "Bildbeschreibung e a cena contemporânea: aspectos da dramaturgia tardia de Heiner Müller", o pesquisador Gustavo Laranja também faz uma abordagem de Descrição de imagem compreendendo o texto como um palimpsesto. Para sustentar tal interpretação o autor da tese recorre a um estudo feito pelo crítico literário francês Gérard Genette ${ }^{16}$, que realiza uma leitura que diverge daquela realizada pelo próprio Müller. O dramaturgo, como citado anteriormente, escreve em sua autobiografia que seu texto é composto de diversos quadros, onde "uma camada apaga sempre a precedente". ${ }^{17}$ A leitura feita por Genette, porém, traz a ideia de um apagamento que nunca é absoluto. Aquilo que é raspado deixa rastros, traços: "toda camada raspada para dar espaço a um novo texto permanecerá sempre acessível, o que confere relevo, no ato da interpretação, à busca das relações entre os diversos palimpsestos (hipertextos) passíveis de identificação". ${ }^{18}$ 
Para finalizar esta parte dedicada a fazer algumas considerações sobre a escrita de Descrição de imagem vale retomar aqui uma suposta segmentação do texto tal como ela foi concebida por alguns estudiosos da obra de Heiner Müller e que Gustavo Laranja apresenta em sua tese. Segundo essa leitura, é possível pensar em cinco segmentos distintos em Descrição de imagem: o primeiro é marcado por ser o momento em que o observador realiza a caracterização inicial da imagem, enumerando os elementos que a compõem. O segundo segmento tem início no trecho em que Müller escreve: "até que a movimentação interminável se instala, rompe o limite"19, e que Laranja descreve como o acontecimento de um "fenômeno catastrófico, a interromper o aparente vão exercício da transposição [da imagem observada para sua descrição]". ${ }^{20}$ No terceiro segmento, o observador provoca um deslocamento temporal, em direção a um passado, que seja capaz de justificar a imagem tal como ela se configura no momento em que é observada. O quarto segmento tem como questão o erro, que é lido no artigo de Gatti como um elemento capaz de alterar a imagem. Por fim, o quinto segmento é marcado por ser o momento em que o observador é colocado em foco e a relação entre aquilo que é visto e aquele que vê é posta em questão.

\section{Recepção: Ler e escutar a descrição de uma imagem}

Feitas algumas breves considerações sobre a escrita em L'image e Descrição de imagem, o foco do trabalho passa a ser, agora, a questão da recepção de tais textos. Considerando as peculiaridades que eles apresentam, é possível problematizar o ato da leitura, bem como o ato da escuta destes textos - considerando, no caso de Descrição de imagem, que a escuta pode se dar tanto no processo de leitura do texto quanto no ato de assistir a uma encenação do texto, visto que ele é concebido por Müller como um texto para o teatro.

A leitura de ambos os textos se dá em um constante movimento de ir e vir, movimento esse que talvez seja ainda mais intenso na obra de Beckett, dado que a ausência de sinais de pontuação abre possibilidades diversas para a compreensão do texto. Ele exige um esforço, por parte do leitor, uma vez que este precisa estabelecer ligações entre as palavras em uma tentativa de construção de algum sentido para o texto lido.

Este movimento de ir e vir na leitura das obras de Beckett e Müller acaba, por consequência, fazendo com que as imagens descritas nos textos entrem em um movimento de aparecimento e de desaparecimento, ou ainda, de velamento e de desvelamento. Pode-se pensar, portanto, que um dos traços mais fortes da recepção de L'image e Descrição de imagem - e que é também um dos elementos marcantes da escrita dessas obras - é a repetição.

A repetição, no entanto, não é pensada aqui como o reaparecimento do mesmo e do idêntico. Na já referida tese de Gustavo Laranja, esta questão da repetição aparece 
fundamentada em estudos da área da Linguística, mais precisamente em estudos feitos pelo linguista russo Roman Jakobson ${ }^{21}$, segundo o qual é possível afirmar que

o reordenamento do material textual, sua combinação em uma nova configuração, tem um impacto evidente sobre o processo de significação. [...] Ao ser retomado em outro momento da descrição, um elemento já se vê emoldurado porém por um novo contexto que, por sua vez, interfere no significado que o termo é capaz de sugerir. ${ }^{22}$

Para exemplificar o uso da repetição, pode-se pensar, no caso de L'image, nas repetidas vezes em que as palavras "mãos" ou "mão" aparecem no decorrer da narrativa: [...] que fazem as mãos durante este tempo devemos sempre ver o que fazem as mãos pois então a esquerda nós a vemos ela sempre leva a bolsa e a direita ah sim a direita ao cabo de um momento eu a vejo lá longe na ponta de seu braço alongado [...]" ${ }^{23} \mathrm{Em}$ outro momento, mais adiante, o olhar daquele que narra se volta novamente para as mãos:

[...] diante de nós imobilidade de estátua exceto os braços as mãos entrelaçadas que se balançam em minha mão livre ou esquerda um objeto indefinível e por consequência na direita dela a extremidade de uma certa deixa conduzindo a um cão terrier de cor cinza $[\ldots] .{ }^{24}$

A repetição está presente também em Descrição de imagem, sendo a figura do pássaro uma, dentre outras, que reaparece em momentos distintos do texto. A primeira aparição do pássaro na descrição se dá no seguinte trecho: "num galho de árvore um pássaro, a folhagem encobre sua identidade, pode ser um abutre ou um pavão ou um abutre com cabeça de pavão, olhar e bico apontado para uma mulher que domina a metade direita da imagem". ${ }^{25}$ Mais adiante: "[...] ou será a mulher, o anjo sedento, que abre a mordidas a goela do pássaro e derrama no copo o sangue de sua garganta aberta, o alimento dos mortos”. ${ }^{26} \mathrm{E}$ há, ainda, já no fim do texto, um novo aparecimento dessa figura: “ [...] a rudeza do esboço como uma expressão do desprezo pelas cobaias homem, pássaro, mulher, a bomba sanguínea do homicídio diário, homem contra pássaro e mulher, mulher contra pássaro e homem, pássaro contra mulher e homem". ${ }^{27}$

Tanto o pássaro de Descrição de imagem quanto as mãos em L'image são descritos em situações diferentes, em lugares diferentes, conferindo um certo movimento às imagens, porém não se trata de um movimento causal, isto é, o fato de as mãos estarem entrelaçadas e balançando na passagem recortada do texto de Beckett não é um efeito ou uma consequência necessária decorrente do momento anterior, em que a mão esquerda levava a bolsa e a direita era vista na ponta do braço. Seja no texto de Beckett, seja no texto de Müller, a retomada, o reaparecimento de algum elemento na descrição, não se dá dentro de uma temporalidade linear, a narrativa é entrecortada por diferentes temporalidades: "ações são projetadas no passado, para no instante seguinte remeterem a um evento futuro". ${ }^{28}$

Há, no artigo de Luciano Gatti, duas notas que podem auxiliar na compreensão da recepção dos textos que estão sendo analisados. Na primeira nota, Gatti faz referência a 
um capítulo da obra The Theater of Heiner Müller, do pesquisador norte-americano Jonathan Kalbe, em que ele faz uma aproximação entre Descrição de imagem e o que nomeia como "obra tardia" de Samuel Beckett:

Dada a indeterminação da imagem, cabe ao espectador construí-la mentalmente ao longo da escuta. Uma vez que a construção mental da imagem atemporal ocorre necessariamente no tempo, a mente não pode evitar de parar repetidamente para ponderar a respeito do que é dito. ${ }^{29}$

Ainda que o artigo escrito por Gatti se detenha em Descrição de imagem, parece possível pensar que o "trânsito entre escrita literária e escrita visual" ${ }^{30}$ que é enfrentado pelo receptor do texto de Müller também é enfrentado pelo receptor de L'image, dada a impossibilidade de separar linguagem e imagem, uma vez que esta é construída naquela. Os próprios títulos das duas obras já colocam o receptor diante da expectativa de uma imagem.

A segunda nota, que também lida com a questão da recepção, é mais pertinente ao trabalho de Müller, pois diz respeito a uma coletividade na recepção, no instante em que se assiste a uma encenação do texto mülleriano, implicando em outras possibilidades receptivas, que estão para além daquelas ligadas ao ato da leitura. Em sua autobiografia, o dramaturgo alemão escreve:

No que se refere à Descrição de uma imagem: isso qualquer um pode fazer, mais ou menos bem e cada um de uma forma diferente. A arte mais avançada é a mais democrática, cada um pode descrever um quadro, a descrição produz novos quadros, quando escrevemos o que nos ocorre durante a descrição. ${ }^{31}$

Gatti cita nesta segunda nota uma passagem de um ensaio de Theresia Birkenhauer, intitulado "Bild-Beschereibung: Das Auge der Sprache" [Descrição de imagem: O olho da fala] ${ }^{32}$, onde a pesquisadora escreve:

Ao ouvir Descrição de imagem, o ouvinte/espectador repete e produz o processo descrito; ele reconstrói e constrói cenas de uma imagem. Essas cenas permanecem sempre incompletas, desfeitas e destruídas pelo intermitente "ou", pela cena seguinte, antes que possam se estabelecer integralmente. Paradoxalmente é esse processo de progressiva interrupção que desorganiza e organiza a visão, que constitui a imagem sempre de novo como algo novo a ser visto. ${ }^{33}$

Contudo, há a possibilidade de se pensar que, ainda que o receptor do texto de Beckett não seja um espectador no teatro, mas um leitor, ainda assim é possível afirmar que ele também, ao ler o texto, está à escuta. Do mesmo modo que um espectador de Descrição de imagem constrói e reconstrói cenas de uma imagem a partir daquilo que ouve e vê, o leitor de L'image realiza o mesmo movimento a partir do que ouve da voz narrativa e do que vê - ler é também ver o texto, percebê-lo visualmente - no texto beckettiano.

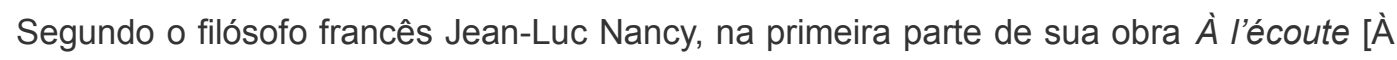
escuta]: 
Estar à escuta é, portanto, entrar na tensão e no acesso de uma relação consigo mesmo: não, é preciso sublinhar, uma relação em "mim" (sujeito supostamente dado) e não mais ao "si" do outro (o falador, o músico, ele também supostamente dado com sua subjetividade), mas a relação em si, se eu posso dizer, tal qual ela forma um "si" ou um "para si" [...] Por esta razão, a escuta - a abertura tensionada à ordem do sonoro, depois à sua amplificação e à sua composição musical - pode e deve nos aparecer como uma figura de acesso ao si, mas como a realidade deste acesso, uma realidade por conseguinte indissociavelmente "minha" e "outra", "singular" e "plural" tanto quanto "material" e "espiritual" e "significante" e "asignificante". ${ }^{34}$

O receptor - seja ele, portanto, leitor e/ou espectador -, ao se colocar à escuta dos textos de Beckett e de Heiner Müller, se coloca em uma relação que, como dito por Nancy, não se dá de um "si" - do autor, do personagem, das vozes que descrevem a imagem - para um "mim" - o receptor. Pelo contrário, este se coloca na "relação em si", ou seja, se situa num entre, em relação, entre o dentro e o fora da obra, entre o que aparece e o que desaparece, entre a escrita e o visual, entre o visível e o sonoro, sendo que, ainda segundo Nancy: "o visual persiste ainda em seu desvanecimento, o sonoro aparece e se desvanece em sua permanência". ${ }^{35}$

\section{Imagem: Fazer a imagem. Descrever a imagem}

Para analisar as imagens construídas em Descrição de imagem e em L'image foram elencados alguns aspectos que permitem a realização da análise: o primeiro aspecto diz respeito às vozes criadas por Müller e Beckett em suas obras, e que são responsáveis pela descrição/criação das imagens; o método descritivo será também pensado neste momento do trabalho. O segundo aspecto é o da dimensão do visível, tendo como objetivo compreender alguns dos problemas implicados nas obras no que diz respeito à visibilidade e à invisibilidade, além de analisar em que medida esses aparecimentos e reaparecimentos estão ligados a uma dimensão temporal das obras. Por fim, o terceiro aspecto diz respeito ao observador em relação à imagem observada.

\subsection{Primeiro aspecto: A voz e a descrição}

O texto beckettiano se inicia da seguinte maneira:

A língua se enche de lama um só remédio a entrar e girar na boca a lama engoli-la ou rejeitá-la questão de saber se ela é nutritiva e perspectivas sem ser obrigado pelo fato de beber frequentemente eu tomo um bocado é um dos meus recursos aguardo um bom momento questão de saber se engolir ela me alimentaria e perspectivas que se abrem não são maus momentos me esforçar tudo está lá a língua volta a sair rosa na lama que fazem as mãos durante esse tempo é preciso sempre ver o que fazem as mãos [...] (BECKETT, 1988, p.9-10). ${ }^{36}$.

As imagens vão sendo construídas por uma voz que parece se deslocar, como um olhar, por diversos pedaços da imagem que ela constrói. Inicia-se dando conta da lama, da 
língua que se enche dessa lama, se deslocando para as mãos, dando ao leitor uma nova perspectiva da imagem, um novo ângulo, um novo ponto de vista. À boca e à língua que estão na lama se junta uma mão direita que parece se abrir e se fechar na lama. $A$ incerteza e a imprecisão são elementos marcantes no decorrer da narrativa: "se isso se pode dizer ou mais ainda se fazer que se abra e se feche na lama se abra e se feche é outro de meus recursos esse pequeno gesto me ajuda eu não sei porque eu gosto disso dos pequenos truques". ${ }^{37}$

Aos poucos vão aparecendo na escrita algumas expressões que parecem criar uma associação entre a voz que narra e o corpo que se encontra na lama, como por exemplo: "eu tomo um bocado [de lama] é um dos meus recursos" 38 , "ela não deve estar longe um metro apenas mas eu a sinto longe" ${ }^{39}$, ou ainda, "sob a lama eu me vejo eu me vejo eu digo mim como eu digo eu como eu diria ele porque isso me diverte". ${ }^{40}$ Essas passagens, dentre outras, dão abertura para uma hipótese interpretativa que compreende essa voz como a consciência desse corpo na lama e a narrativa seria, portanto, um fluxo ininterrupto dessa consciência - resguardados aqui os nós envolvidos nesse conceito e o perigo de subjetivar essa voz, o que resultaria em uma leitura psicologizante e equivocada. A voz se constitui como um sujeito da enunciação, não como um "em si", mas como sujeito situado na tensão entre imagem e linguagem, na cisão entre o "eu" (sujeito) e o "me"/"mim" (objeto), isto é, o narrador, ao mesmo tempo que se vê, se vê como outro, mas essa cisão será tema de análise mais adiante.

Há um momento do texto em que o narrador diz que imagina: "a cabeça jogada para trás nós assistimos eu imagino reto diante de nós imobilidade de estátua exceto os braços". ${ }^{41}$ Imaginar, neste caso, está relacionado ao ato de fazer histórias, o que pode ser pensado, por sua vez, como um ato de fazer imagens. Apesar da lama, apesar da boca, língua e mãos na lama, ainda é possível fazer imagens, histórias de animais, de flores e de estações, que o narrador desconhece de onde as tira, mas fazê-las é manter-se vivo.

No texto de Heiner Müller o movimento inicial é o de uma descrição: "Uma paisagem entre estepe e savana, o céu de um azul prussiano, duas nuvens flutuando lá dentro, como que unidas por esqueletos de arame"42, mas, assim como em L'image, não se sabe quem observa nem de onde observa. Rompendo com as convenções teatrais, Müller não escreve rubricas com indicações de ordem espacial e/ou temporal, somente se sabe que há um observador - ou há somente sua voz - que tenta realizar aquilo que já está dito no título do texto, a descrição de uma imagem.

Mas em que consiste a descrição de uma imagem? Contrariando a ideia de que a descrição consiste em uma atividade simples, Jean Jourdheuil afirma que "o ato de descrever uma imagem não é um empreendimento literário banal" ${ }^{43}$ e diz ser "notável a forma com que Müller inscreve seu texto no registro das artes plásticas". ${ }^{44}$ Outro francês, o filósofo Jacques Rancière, no terceiro capítulo de seu livro O destino das imagens, intitulado "A pintura no texto", se lança em uma reflexão sobre esse complicado 
deslocamento do visual (imagem) para a escrita (texto).

Para discutir esse deslocamento entre meios distintos, Rancière recorre a dois exemplos de textos críticos, sendo um escrito pelos irmãos Edmond e Jules de Goncourt, em 1864, sobre o pintor francês Jean-Baptiste-Siméon Chardin, e o outro escrito por Albert Aurier, em 1890, a partir da obra Visão depois do sermão, de Gauguin.

No primeiro exemplo, escrevem os irmãos Goncourt:

sobre uma dessas mesas com tons de musgo, de mármore terroso, na qual habitualmente ele inscreve sua assinatura, Chardin despeja os pratos de uma sobremesa - aqui está o veludo felpado do pêssego, a transparência de âmbar da uva branca, o orvalho de açúcar da ameixa [...]. ${ }^{45}$

O que está em jogo nesta passagem é que a descrição feita pelos Goncourt produz uma nova visibilidade ou, nas palavras de Rancière, o que se dá é a "operação de uma mão que anula um visível para produzir outro visível: uma visibilidade 'total', a visibilidade do gesto da pintura que substitui o seu resultado". ${ }^{46}$

O segundo exemplo a que recorre Rancière se vale do jogo entre visibilidade e invisibilidade, isto é, realiza uma descrição que lança mão de elementos que não são visíveis no quadro produzindo, dessa maneira, um novo status, para usar o termo do filósofo, para o visível do quadro:

Longe, muito longe, numa fabulosa colina, cujo solo aparece em vermelho rútilo, está a luta bíblica de Jacó com o Anjo.

Enquanto esses dois gigantes de lenda, que o distanciamento transforma em pigmeus, enfrentam seu formidável combate, mulheres olham, interessadas, provavelmente sem compreender muito bem o que acontece ali, no alto da fabulosa colina púrpura. [...] diríamos que estão numa igreja e que um vago odor de incenso e de prece volteia, entre as asas brancas de seus chapéus, e que uma voz respeitada de velho padre paira sobre suas cabeças [...] sua pobre, velha e lamentável Voz tarcamuda que se tornou visível, imperiosamente visível, e é sua Voz que contemplam com atenção ingênua e devota as camponesas de chapéus brancos". 47

A descrição feita por Aurier, segundo Rancière, "é construída no jogo do enigma e das substituições. Ela põe uma cena de palavra no lugar de outra". ${ }^{48}$ Essas "cenas de palavras" a que se refere Rancière apontam para o invisível que a palavra torna visível como é o caso do "odor de incenso", por exemplo. A descrição é também, de um certo modo, uma interrogação sobre aquilo que se observa. Dizer que as mulheres presentes na obra de Gauguin estão em uma igreja ou que ouvem a voz de um padre são suposições que derivam, dentre outros motivos, da postura que elas apresentam na pintura. O mesmo acontece em Descrição de imagem quando o observador, a partir de um detalhe do desenho - "uma segunda cadeira está jogada à direita atrás da árvore, o espaldar quebrado" 49 - cria cenários/situações que possam justificar tal configuração: 
"que peso quebrou a cadeira, desestabilizou a outra, um assassinato talvez, ou um ato sexual selvagem, ou os dois em um". ${ }^{50}$

Pensada desta maneira, a descrição envolve o que Gustavo Laranja chama, em sua tese, de "ativação da consciência do observador [...] o impasse hermenêutico caminha lado a lado com uma consciência que parece apontar para a impossibilidade de toda forma de representação". ${ }^{51} \mathrm{O}$ autor ainda defende a hipótese de que, em Descrição de imagem, essa consciência do observador aparece, por exemplo, no uso das palavras escritas em letra maiúscula, estabelecendo "uma relação dialógica entre o objeto descrito e o modo de descrevê-lo. A escrita mülleriana tematiza, assim, a relação entre literatura e artes visuais em ao menos dois planos: o dos objetos representados e o do modo de representar". ${ }^{52}$ Essa relação tematizada nas obras de Müller e de Beckett problematiza a própria ideia de uma instância visível nesses textos, e este será o próximo aspecto a ser analisado.

\subsection{Segundo aspecto: $O$ visível e o tempo}

O olhar é um dos temas abordados nos dois textos que estão sendo aqui trabalhados. Sobre o olhar, em Descrição de imagem, escreve Ruth Röhl, em um texto chamado "Heiner Müller na pós-modernidade", que a

peça apresenta a ação de dois olhares - um olhar petrificador, equivalente ao do sol, e um segundo olhar que se situa no espaço de um 'piscar de olhos', olhar desestabilizador que dissolve a forma fechada, eternizável, da imagem, exemplificando uma nova forma de ver. ${ }^{53}$

O artigo de Luciano Gatti e a tese de Gustavo Laranja seguem o mesmo raciocínio de Röhl, ao afirmarem que o texto de Müller propõe uma nova relação entre o visível e o invisível, se afastando da noção de "instante pregnante" concebida pelo filósofo, poeta, dramaturgo e crítico de arte alemão, Lessing, em sua obra Laocoonte, onde trata dos limites das artes visuais e da poesia. Sobre o "instante pregnante" de Lessing, escreve Gatti:

O caráter inicialmente estático do objeto é então temporalmente qualificado como um instante de sua existência temporal e daí extrai uma instrução normativa para as artes visuais: a obra de arte visual, pela coexistência das partes em suas composições, só pode valer-se de um único momento. e por isso deve escolher o mais pregnante, o mais sugestivo do que veio antes e do que vier depois. ${ }^{54}$

Há, em Lessing, a noção de um momento que causa em si, em sua imobilidade, o antes e o depois na configuração de uma imagem. Em L'image e em Descrição de imagem, a visualidade se configura de um modo absolutamente oposto ao proposto por Lessing. Não há, nesses textos a tentativa de fixar um instante presente, mas ao contrário, as imagens surgem a partir de enunciações justapostas, que remetem a temporalidades 
diversas. Como escreve Gatti: "pelo trabalho de descrição, surgem fragmentos de ações possíveis, mas nenhuma delas fecha o círculo da ação inteira e acabada". ${ }^{55}$

Para compreender melhor esse inacabamento do qual fala Gatti, vale a pena retomar a passagem do texto de Heiner Müller em que o observador se detém no detalhe da cadeira com o espaldar quebrado, pois desse detalhe derivam vários cenários possíveis, criados pelo observador numa tentativa de compreender o que provocou a quebra da cadeira, fazendo com que a narrativa se desloque para um passado - invisível na imagem -, mas que se relaciona com eventos futuros, porém sem estabelecer uma relação de causa e consequência. A primeira possibilidade criada pelo observador para o espaldar quebrado é a de um ato sexual:

o homem na cadeira, a mulher sobre ele, o membro dele em sua vagina, a mulher ainda carregada do peso da terra do túmulo de onde saiu para visitar o homem, da água subterrânea que seu casaco de pele escorre, seu movimento primeiro um balançar suave, depois um cavalgar impetuoso e progressivo até que o orgasmo comprime as costas do homem contra o espaldar da cadeira, que cede estalando..$^{56}$

Na sequência, a imagem do casal em uma relação sexual desvanece fazendo aparecer a outra possibilidade criada pelo observador para a cadeira quebrada, um assassinato, onde o homem vai, aos poucos, fechando suas mãos no pescoço da mulher, estrangulando-a,

até que as mãos da mulher desabam dos braços dele e o leve estalar do pomo-de-adão ou da vértebra do pescoço indicam o final do trabalho, talvez agora, com o peso novamente morto, quando o homem recolhe as mãos, o espaldar da cadeira ceda ou a mulher caia para a frente com o rosto vermelhoazul sobre o copo de vinho. ${ }^{57}$

Estas duas passagens extraídas do texto de Heiner Müller demonstram o que Ruth Röhl chama de visibilidade característica do "piscar de olhos" que, segundo Gatti, desata "um processo narrativo que nunca se totaliza. Nesse sentido, vê-se que a narrativa é inserida para que dela possa emergir a irrupção, a hesitação, o instante fugaz, que não perdura, mas surge e desaparece num relampejar". ${ }^{58}$ Uma imagem, portanto, nunca é uma imagem única, ela é carregada de outras imagens, por isso é possível a Aurier falar sobre a voz do padre que se faz visível no quadro, sobre o odor de incenso e, também por esse mesmo motivo, é possível ao observador de Descrição de imagem dizer sobre um ato sexual ou um assassinato a partir de uma cadeira com o espaldar quebrado.

Associada a esse turbilhão de imagens, há uma dimensão temporal, afinal, toda imagem é atravessada por distintos tempos, seja o tempo em que foi produzida, seja o tempo da recepção dela em épocas diferentes, ou ainda, tempos diferentes no interior da própria imagem.

É possível destacar, em L'image, por exemplo, momentos em que se percebem esses atravessamentos de tempos diversos, assim como momentos em que a visibilidade 
parece ser problematizada. Sobre a dimensão temporal, pode-se recortar o seguinte momento do texto de Beckett: "eu me vejo com dezesseis anos e para coroar o momento de felicidade um tempo delicioso céu azul-ovo e cavalgado de pequenas nuvens [...] a julgar pelas flores que se espalham a erva esmeralda nós estamos no mês de abril ou maio". ${ }^{59}$ Ainda que haja uma certa precisão por parte do narrador ao afirmar que se vê com dezesseis anos, a descrição da imagem ainda apresenta incertezas e imprecisões, que são identificadas pelo uso do termo "ou" e pela expressão "a julgar".

Sobre o visível, pode-se recortar um trecho mais adiante, onde se lê: "degustação em silêncio do mar e das ilhas cabeças que rodam como uma só em direção às fumaças da cidade reconhecimento em silêncio dos monumentos cabeças que voltam diríamos ligadas por um eixo breve neblina e nós comendo os sanduíches". ${ }^{60}$ Há, aqui, a presença de uma "breve neblina" que pode ser pensada como um elemento que dificulta a visualização, que deixa a imagem embaçada e não se sabe, também, se essa imagem corresponde a uma memória do narrador ou se é uma construção da sua imaginação.

A imagem fica embaçada novamente, já no fim do texto, devido à presença de um nevoeiro, provocando uma dificuldade ao narrador para ver e descrever a imagem. Há um processo de apagamento dela, o que dá margem para pensar que no ato de ver está também implicado o não ver, fazer a imagem é dizer - ou tentar dizer - sobre aquilo que aparece e desaparece, tanto que só é dito que a imagem está feita quando não há o que ser visto, como se lê no final da obra:

os braços se balançando a cabeça alta em direção aos cumes cada vez menores eu não vejo mais o cão eu não nos vejo mais a cena está embaçada alguns animais as ovelhas que diríamos que parece de granito um cavalo que eu não tinha um visto no início [...] sob a lama terminou está feito isso se apaga a cena fica vazia alguns animais depois se apaga [...] eu fico lá lá longe à direita na lama a mão se abre e se fecha [...] eu me dou conta que eu sorrio ainda e não vale mais a pena desde muito tempo [...] a língua volta a boca se fecha ela deve fazer uma linha reta agora está feito eu fiz a imagem. ${ }^{61}$

A primeira e esta última passagem retiradas de L'image apontam para o terceiro aspecto que será analisado nesse trabalho, que diz respeito à cisão entre o ver e o ser visto, entre a imagem observada e o sujeito que a observa. Quando o narrador diz "eu me vejo" ele se fragmenta, estabelece uma dupla relação consigo mesmo e é essa relação que será abordada na sequência.

\subsection{Terceiro aspecto: Ver e ser visto}

O texto de Samuel Beckett apresenta a questão do ver e do ser visto nos momentos em que o narrador afirma se ver, ou seja, há um deslocamento e um descolamento daquele que faz a imagem para a própria imagem, ele se vê na imagem que descreve - ou faz. Essa dupla condição do narrador, de sujeito e de objeto, de "narrador" e de "objeto narrado", aparece de modo mais claro quando o narrador diz: "de repente lá sob a lama 
eu me vejo eu digo mim como eu digo eu como eu diria ele porque isso me diverte [...]". ${ }^{62}$

Já no texto de Heiner Müller o observador, até o momento em que aparece pela primeira vez a palavra "EU", é invisível, ele descreve a imagem de fora dela, ele se encontra, de certo modo, em uma situação de estabilidade. A descrição é permeada por incertezas, mas o lugar do observador não é posto em questão, o dentro e o fora da imagem não se confundem, observador e imagem observada não se misturam, não se fundem.

No final do texto, porém, ele como que se dilui na imagem, parece que esta absorve aquele que, até então, a descrevia; ele parece invadir o mundo desses mortos que ocupam a imagem. Descrição e imagem permanecem como domínios distintos até o instante em que o observador passa a assumir o lugar das figuras que ocupam a imagem:

o homem com o passo de dança EU, meu túmulo seu rosto, EU a mulher com a ferida no pescoço, à direita e à esquerda nas mãos o pássaro partido, sangue na boca, EU $O$ PÁSSARO, aquele que com a escrita de seu bico mostra ao assassino o caminho da noite, EU a tempestade gelada. ${ }^{63}$

$\mathrm{Na}$ tentativa de compreender essa cisão entre sujeito e objeto, Luciano Gatti apresenta em seu artigo algumas interpretações feitas por estudiosos da obra de Heiner Müller, como, por exemplo, o teórico alemão Hans-Thies Lehmann, que compreende que "há um sujeito cindido entre dois olhares, incapaz de guardar distância do outro e definir-se como instância autônoma e autocentrada" ${ }^{64}$

Já para Theresia Birkenhauer o que ocorre nesse momento final do texto é a

dissolução da dicotomia por meio de uma ontologia da linguagem [...] movendo-se na vizinhança da morte do autor, e caracterizando o 'EU' como uma instância despersonalizada, anônima, não determinada ou determinável, que emerge pela primeira vez na escrita como metamorfose de todas as suas figuras. ${ }^{65}$

Ao caracterizar o "EU" como "instância despersonalizada", retoma-se aqui uma ideia já abordada anteriormente neste trabalho, a saber, que ambos os narradores, o de L'image e o de Descrição de imagem, não podem ser pensados como subjetividades, eles se constituem como sujeitos da enunciação que emergem "pela primeira vez na escrita" ou, em outras palavras, eles emergem na linguagem e é nela que assumem a condição de observadores, mas também a de "fazedores de imagem". Situam-se em um conflito que Gatti nomeia como "confronto com a alteridade da imagem de si" ${ }^{\prime \prime}$, isto é, o sujeito - ele próprio, uma imagem - questiona sua identidade a partir da imagem que cria de si mesmo. 
* Danilo Riva Moraes é mestre em artes cênicas pela UniRio.

${ }^{1}$ BECKETT, S. L'image. Paris: Les Éditions de Minuit, 1988, p. 12. No original: "[...] en juger par les fleurs qui émaillent l'herbe émeraude nous sommes au mois d'avril ou de mai j'ignore et avec quelle joie d'où je tiens ces histoires de fleurs et de saisons je les tiens un point c'est tout à en juger par certains accessoires dont une barrière blanche et une tribune d'un rouge exquis nous sommes sur un champ de courses [...]".

${ }^{2}$ Ibidem, p. 13. No original: "[...] peu à peu de taches grises et blanches auxquelles je ne tarde pas à donner le nom d'agneaux au milieu de leurs mères j'ignore d'où je tiens ces histoires d'animaux je les tiens un point c'est tout dans un bon jour je sais nommer quatre ou cinq chiens de race totalement différente $[\ldots]$ ".

${ }^{3}$ Referência ao círculo de Stefan George (1868-1933), poeta alemão que divergia de Adorno e Benjamin, por exemplo, na interpretação das poesias de Hölderlin.

${ }^{4}$ ADORNO, T. W. "Sinais de pontuação". In: Notas de literatura I. São Paulo: Duas Cidades; Editora 34, 2003, pp. 141-142.

${ }^{5}$ Ibidem, p. 142.

${ }^{6}$ BECKET, S. Op. cit., p. 9. Na tradução: "A língua se enche de lama". Este foi o único trecho citado no original para manter, no corpo do texto, a mesma letra que se encontra grafada no texto original.

${ }^{7}$ MÜLLER, H. Guerra sem batalha: uma vida entre duas ditaduras. São Paulo: Estação Liberdade, 1997, p. 249.

8 GATTI, L. "Espaços livres para a fantasia: Descrição de imagem, de Heiner Müller". In: Pandaemonium, v.16, n. 22 (dez/2013), pp.101-121, aqui p. 109.

${ }^{9}$ RÖHL, R. O teatro de Heiner Müller. São Paulo: Perspectiva, 1997, p. 27.

${ }^{10} \mathrm{O}$ dicionário Aurélio da língua portuguesa traz as seguintes definições de palimpsesto: "1. Antigo material de escrita, esp. o pergaminho, que, devido à sua escassez, era us. mais de uma vez. 2. Manuscrito sob cujo texto se descobre $(\mathrm{m})$ a(s) escrita(s) anterior(es)" (Dicionário Aurélio da Língua Portuguesa. Curitiba: Positivo, 2010, p. 558).

11 JOURDHEUIL, J. Heiner Müller: La Fracture. Europa: Revue d'actualité politique, littéraire et artistique, 2006. Disponível em: <http://www.sine-causa.com/er/arte/theater/hm/hm02.htm>. Acesso em 13.03.2018. No original: "Bildbeschreibung peut être considérée comme un palimpseste d'images et de références issues d'Alceste, du jeu de Nô Kumasaka, du onzième chant de l'Odysée, des Oiseaux d'Hitchcock et de La Tempête de Shakespeare".

12 Ibidem. No original: "réseau complexe de relations littéraires".

${ }^{13}$ Francis Bacon (1909-1992), pintor irlandês, autor do quadro Estudo sobre a obra Papa Inocêncio $X$ (1953), que é um palimpsesto da obra Papa Inocencio $X$ (1650), do pintor espanhol Diego Velázquez (1599-1660).

${ }^{14}$ Ibidem. No original: "qui est un palimpseste du portrait d'un pape par Velasquez, ou aux Ménines de Picasso qui sont un palimpseste du tableau homonyme du même Velasquez".

${ }^{15}$ Ibidem. No original: "objet d'un palimpseste, le premier des Cantos d'Ezra Pound, et c'est encore Ezra Pound qui le conduisit à s'intéresser au No Kumasaka”.

${ }^{16}$ GENETTE, G. Palimpsestes: La littérature au second degré. Paris: Seuil, 1982.

${ }^{17}$ MÜLLER, H. Op. cit., p. 249. 
${ }^{18}$ LARANJA, G. R. A. "Bildbeschreibung e a cena contemporânea: aspectos da dramaturgia tardia de Heiner Müller". Tese (Doutorado em Estudos Literários). Curitiba: Universidade Federal do Paraná, 2009, pp. 107-108.

${ }^{19}$ MÜLLER, H. Descrição de imagem. In: Medeamaterial e outros textos. São Paulo:

Paz e Terra, 1993, p. 154.

${ }^{20}$ LARANJA, G. Op. cit., p. 91.

${ }^{21}$ JAKOBSON, R. Linguística e comunicação. São Paulo: Cultrix, 1995.

${ }^{22}$ LARANJA, G. Op. cit., p. 93.

${ }^{23}$ BECKETT, S. Op. cit., pp. 9-10. No original: "[...] que font les mains pendant ce temps il faut toujours voir ce que font les mains eh bien la gauche nous l'avons vu tient toujours le sac et la droite eh bien la droite au bout d'un moment je la vois là-bas au bout de son bras allongé [...]".

${ }^{24}$ Ibidem, p. 12. No original: "[...] devant nous immobilité de statue à parte les bras aux mains entrelacées qui se balancent dans ma main libre ou gauche um objet indéfinissable et par conséquent dans sa droite à elle l'extremité d'une courte laisse conduisant à un chien terrier couleur de cendre $[\ldots] "$.

${ }^{25}$ MÜLLER, H. Descrição de imagem. Op. cit., p. 158.

${ }^{26}$ Ibidem, p. 156.

${ }^{27}$ Ibidem, p. 158.

${ }^{28}$ LARANJA, G. Op. cit., p. 93.

${ }^{29}$ GATTI, L. Op. cit., p. 118.

${ }^{30}$ Ibidem.

${ }^{31}$ MÜLLER, H. Guerra sem batalha: uma vida entre duas ditaduras. Op. cit., p. 250.

${ }^{32}$ Ensaio sem tradução para o português. A tradução citada neste trabalho foi feita por Luciano Gatti em seu artigo.

${ }^{33}$ BIRKENHAUER apud GATTI, L. Op. cit., pp. 118-119.

${ }^{34}$ NANCY, J.-L. À l'écoute. Paris: Éditions Galilée, 2002, pp. 30-31. Grifo do autor. Obra sem tradução para o português. A citação feita neste trabalho foi feita por mim, tendo por base a versão original, em francês e a tradução para a língua espanhola.

35 Ibidem, p. 14.

${ }^{36}$ BECKETT, S. Op. cit., pp. 9-10. No original: "La langue se charge de boue un seul remède alors la rentrer et la tourner dans la bouche la boue l'avaler ou la rejeter question de savoir si elle est nourrissante et perspectives sans y être obligé par le fait de boire solvente j'em prends une bouchée c'est une de mês ressources la garde un bon moment question de savoir si avalée elle me nourrirait et perspectives qui s'ouvrent ce ne sont pas de mauvais moments me dépenser tout est lá la langue ressort rose dans la boue que font les mains pendant ce temps il faut toujours voir ce que font les mains [...]".

${ }^{37}$ Ibidem, p. 10. No original: "si ça peut se dire ou plutôt se faire qui s'ouvre et se referme dans la boue s'ouvre et se referme c'est une autre de mes ressources ce petit geste m'aide je ne sais pourquoi j'ai comme ça des petits trucs [...]".

${ }^{38}$ Ibidem, p. 9. No original: "j'en prends une bouchée c'est une de mes ressources".

${ }^{39}$ Ibidem, p. 10. No original: "elle ne doit pas être bien loin un mètre à peine mais je la sens loin".

${ }^{40}$ Ibidem. No original: "sous la boue je me vois je dis me comme je dis je comme je dirais il parce que ça m'amuse". 
${ }^{41}$ Ibidem, p.12. No original: "la tête rejetée em arrière nous regardons j'imagine droit devant nous immobilité de statue à part les bras".

${ }^{42}$ MÜLLER, H. Descrição de imagem. Op. cit., p.153.

43 JOURDHEUIL, J. Op. cit. No original: "Le fait de décrire une image n'est pas une entreprise littéraire banale".

${ }^{44}$ Ibidem. No original: "Remarquable ici la façon qu'a Müller d'inscrire ses textes au registre des arts plastiques".

${ }^{45}$ GONCOURT, E.; GONCOURT, J. apud RANCIĖRE, J. "A pintura no texto". In: . 0 destino das imagens. Tradução de Mônica Costa Netto. Rio de Janeiro: Contraponto, 2012, p. 90.

46 Ibidem, p. 91.

${ }^{47}$ AURIER, A. apud RANCIĖRE, J. Op. cit., pp. 93-95.

${ }^{48}$ Ibidem, p. 95.

${ }^{49}$ MÜLLER, H. Descrição de imagem. Op. cit., p. 155.

50 lbidem.

${ }^{51}$ LARANJA, G. Op. cit., p. 94.

52 Ibidem.

${ }^{53}$ RÖHL, R. "Heiner Müller na pós-modernidade". In: . KOUDELA, I. D. (org.) Heiner Müller: O espanto no teatro. São Paulo: Perspectiva, 2003, pp. 33- 41, aqui p. 39.

${ }^{54}$ GATTI, L. Op. cit., p. 108.

${ }^{55}$ Ibidem, pp. 108-109.

${ }^{56}$ MÜLLER, H. Descrição de imagem. Op. cit., p. 155.

${ }^{57}$ Ibidem, p. 156.

${ }^{58}$ GATTI, L. Op. cit., p. 113-114.

${ }^{59}$ BECKETT, S. Op. cit., pp. 11-12.

${ }^{60}$ Ibidem, p.16. No original: "[...] dégustation em silence de la mer et des îles têtes qui pivotent comme une seule vers les fumées de la cité repérage em silence des monuments têtes qui reviennent on dirait reliées par un essieu bref brouillard et nous revoilà qui mangeons les sandwichs [...]"

${ }^{61}$ Ibidem, p. 18. No original: "[...] les bras se balançant la tête haute vers les sommets de plus en plus petits je ne vois plus de chien je ne nous vois olus la scène est débarrassée quelques bêtes les moutons qu'on dirait du granit qui affleure un cheval que je n'avais pas vou debout [...] sous la boue c'est fini c'est fait ça s'éteint la scène reste vide quelques bêtes puis s'éteint [...] je reste là làbas à droite dans la boue la main s'ouvre et se referme [...] je me rends compte que je souris encore ce n'est plus la peine depuis longtemps [...] la langue rentre la bouche se referme elle doit fair une ligne droite à présent c'est fait j'ai fait l'image [...]".

62 Ibidem, p. 11.

${ }^{63}$ MÜLLER, H. Descrição de imagem. Op. cit., pp. 158-159.

${ }^{64}$ GATTI, L. Op. cit., p. 115.

${ }^{65}$ Ibidem.

${ }^{66}$ Ibidem, p. 117. 